\title{
The cost of maintenance
}

Werner Gries reports from Bonn on West Germany's funding for science

West Germany spent DM24,200 million on scientific research and development in 1976: DM12,700 million came from the government, DM10,900 million from industry and the remainder from overseas and from independent foundations. As is customary, $55 \%$ of the government contribution was raised by the central government, and $45 \%$ by the Länder which comprise the federal republic. In contrast to other Western nations, military research and development plays a comparatively minor role in West Germany: in 1976 it received DM1,500 million-6\% of the total research expenditure. Since 1973 there has been no increase in the resources available for research and development and plans for 1977 show that in real terms, total expenditure on research will decrease. In $19762.2 \%$ of GNP was spent on scientific research.

Non-nuclear energy research is receiving increasing support from both the government and industry. The government contribution for specific projects connected with nonnuclear energy amounts to DM270 million in 1977. Some DM300 million will be spent on research centres and other projects. Mining and coal technology are the most important areas receiving government subsidy. New techniques of searching for and developing petroleum, natural gas and uranium are also being investigated, as are the possibilities of solar and wind energy. Solar collectors for heating are now so advanced that the government is considering offering special incentives, particularly investment bonuses, to encourage manfacturers to put new techniques on the market. The government is also subsidising research into new methods of saving energy.

On the nuclear front, West Germany is, amongst other things, developing the fast breeder reactor. About 2,300 people are now employed on the development work and in 1977 about DM380 million will be made available to research establishments and industry for further development. The principal project is the $300 \mathrm{MW}$ prototype reactor at Kalkar, which according to the latest estimates will cost DM2,800 million to set up. A smaller experimental reactor is being built in Karlsruhe to test the fuel elements for the fast breeder. Plans are also going ahead for the construction of larger fast breeder reactors in collaboration with France. German electricity supply companies are involved in the construction of the French Super-Phenix, for which they are receiving a grant of DM55 million from the West German government.

The Ministry of Research and Technology is in charge of all government activities in the field of fast breeder development, and although there is growing opposition to these reactors in parliament, the Ministry apparently intends to continue promoting intensive research on them. So far the government alone has spent DM2,100 million on the development of fast breeder reactors. In addition to the prototype at Kalkar, a large fast breeder reactor is scheduled to be built in the early 1980 s. Its construction will take into account the results of the French project; there has been close cooperation between France and West Germany on fast breeder development since the treaty between the two countries in 1975.

In 1977 space research will receive DM600 million almost exclusively from the government, and in particular from the Ministry of Research and Technology: DM347 million will go to the European Space Agency and form the major part of West Germany's spending on space research. At the moment the West German government is primarily involved in financing the ESA Spacelab and in the development of various exploratory satellites. It gives DM 40 million a year towards developing the launcher Ariane; an extra DM 10 million will go towards the building of a launching base for the Ariane in Kourou in French Guiana.

Support for national space projects has decreased steadily in the past few years and now only $20 \%$ of the total expenditure goes on domestic projects. In 1977 DM133 million will be spent on a large research establishment for air and space travel, Deutsche Forschung-und Versuchsanstalt für Luft und Raumfahrt (DFVLR).

\section{A catalytic note}

Wendy Barnaby reports from Stockholm on Sweden's recently established Energy Institute

SWEDEN's new international Energy Institute, opened recently in Stockholm, is planning to carve a niche for itself in research on energy/ecology problems. It will see man's use of energy as a special case of the energy flow in the biosphere, affecting it and all natuial resources. This should be a suitable focus for the new Director, Professor Gordon Goodman, a British ecologist with wide experience in energy research, and it is in line with the interests of the chairman of the international board, Professor Jack
Hollander, an American who heads a large project on energy for the US Academy of Science.

Specific research projects will depend largely on the results of the review of current energy research that Goodman and a plasma physicist, Lars Kristoferson, are about to begin--both want energy researchers to notify them of projects being done. The idea is to close those gaps created by the transdisciplinary nature, long time-scale or low economic interest of the work needed to fill them. The Institute will not therefore be interested in shortterm, controversial topics; Goodman wants to establish its reputation as a trusted supplier of timely and significant facts for the international debate on energy-related problems. $\mathrm{He}$ envisages the Institute playing a catalytic role by preparing review papers highlighting the need for research in various areas. As it has no laboratory facilities, its work will be carried on by seminars, symposia and publications.

The Institute's funds are very limited-about $\$ 400,000$ a year for the next seven years from the private Beijer Foundation-and additional funds will have to be sought elsewhere to get a reasonable programme going. But Goodman points out that the money has no strings attached and will enable the Institute to avoid projects meant to bolster sectarian interests. Because of the financial limitations, permanent positions will probably be limited to the Director and his assistant; academics coming to Stockholm for short visits or sabbaticals would help carry out projects. 